\title{
FOREIGN ASSISTANCE AND CONSUMPTION INEQUALITY: DOES THE STRUCTURE OF AID MATTER?
}

\section{NESTOR CHERYBA ${ }^{a}$ \\ ${ }^{a}$ Kyiv School of Economics, Kyiv, Ukraine \\ E-mail: ncheryba@kse.org.ua}

\begin{abstract}
This paper uses a dataset of 75 countries covering 1960-2010 to examine whether foreign aid has any effect on consumption inequality. The variable of assistance is split into grants and loans - the central hypothesis being different non-linear impact of each on inequality - with the impact of loans being hump-shaped and grants "U"-shaped. The results corroborate the direction and the type of impact that foreign assistance has on inequality. In addition, the outcomes for quartile data subsets show that the relationships between foreign assistance and inequality differ depending on a country's GDP per capita. However, the hypothesis regarding the influence of coup d'états hasn't been confirmed.
\end{abstract}

JEL Codes F35, D63, O50, H81

Keywords foreign aid, grants, loans, consumption inequality, government overthrow

\section{INTRODUCTION}

It is well-established that income inequality is harmful to development and prosperity. Income inequality has detrimental effects on the credit markets (Aghion and Bolton, 1997), may cause economic crises (Piketty and Saez, 2003), and slows down recovery after crises (Stiglitz, 2012). Attempts to reduce poverty and income inequality intensified in 2000 with the establishment of the Millennium Development Goals (UN, 2005) as one of the main instruments of the international community being foreign aid.

The importance of foreign assistance in combatting poverty cannot be overestimated. The Organization of Economic Cooperation and Development (OECD) suggests that foreign aid is the primary way in which developed countries can help to alleviate poverty in the developing world (OECD, 2006) and the official rhetoric of donor organizations states that economic growth is a direct consequence of poverty reduction (Keeley, 2012). Due to these assumptions, for the last two decades, the international community has poured its resources into foreign aid in hopes of alleviating poverty, prompting the amount of external development assistance (ODA) distributed to developing countries to more than double (Figure 1). Despite the best efforts of the international community, income inequality has persisted in the developing world (Ravallion, 2014).

However, empirical studies are inconclusive as to the direct connection between economic growth and poverty reduction. According to Basu and Stiglitz (2016), the claim that development causes a decrease in inequality is doubtful. This "straightforward" view was challenged in 2006 when the World Development Report on Equity and Development was published. The report concludes that the

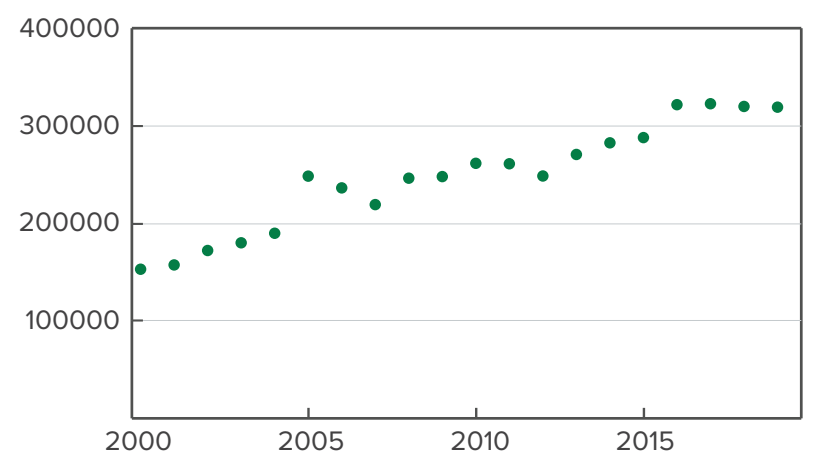

Figure 1. Total Yearly ODA Sent to Developing Countries in 2015 USD Sources: OECD https://data.oecd.org/oda/net-oda.htm\#indicator-chart.

reduction of inequality isn't necessarily a consequence of economic growth and that inequality matters when it comes to improving economic efficiency (World Bank, 2006). The abovementioned arguments suggest that the impact on income distribution remains a relatively new avenue of studies that should be explored in depth.

The other avenue that has not been explored in the available literature is the differing effect of loans and grants on income inequality. Fiala (2018) finds that when comparing the influence of microfinancing via loans and grants in Uganda, only loans increase the sales of a firm. These findings imply that when faced with the condition of repayment, entrepreneurs allocate their investments more efficiently. Morrissey et al. (2006) reach a different conclusion when studying the effects of grants and loans. They conclude that grants are preferred to loans as they don't impose an obligation to repay them in the future as 
loans do. Bulow and Rogoff (2005) also find that borrowing from development banks encourages more lending by the developing countries, which retards development. Though the current literature mostly looks into the effect on economic growth, their methodology may be used for studying the effect on income inequality.

This article studies the efficiency of foreign aid in alleviating income inequality of emerging economies depending on the foreign aid type. The hypothesis is that the impact of foreign assistance is ambiguous and depends on the type of aid being sent to the recipient country. If the aid is given with the condition of returning the credit at a later date, it will have an inequality-reducing effect as the money will be allocated more efficiently. On the other hand, if there is no constraint of returning the money, it will only temporarily boost the household's consumption, but will not have a significant effect on income distribution. Some previous research by Sanford (2002) shows that the influence of grants and loans is indeed different, and the question as to which form of aid is more efficient is still open.

The main contribution of the article is the deconstruction of foreign aid's influence on income inequality by studying the simultaneous effects of foreign loans and grants, the addition of the variable for the cases of violent regime changes and the use of a new dataset on income inequality.

The use of the regime change variable is interesting as existing studies (e.g., Masaki, 2016, Haggard and Kaufman, 2012 , etc.) confirm the existence of the relationship between episodes of violent regime change and foreign aid and income inequality. Hence, the addition of this variable to the regression may help eliminate the omitted variable bias of the dependent variables.

Concerning the data, this work uses the Global Consumption and Income Project inequality database, which hasn't been used in the literature yet. This dataset allows for evaluating models based on the data from 75 countries in 1961-2010 (see Appendix A1 for the full list of countries). The main advantage of this dataset over others used in the literature is the availability of more country years and fewer gaps in the data. These data are also available for both consumption and income-based Gini; this feature allows for additional robustness checks.

The main issue with the full dataset is gaps in the periods that are also aligned with episodes of violent regime changes. In many cases, some observations were not collected due to the overthrow of the government in the country of interest. These gaps may prove to be an issue for the model itself and the role of the variable of violent regime change in particular. Another issue is the fact that the model doesn't consider the effects of grants and loans that are given based on the condition of a particular reform (i.e., loans are broken up into tranches and given only when the country implements a set of reforms that is required to receive the next installment). Unfortunately, such data are unavailable for the current dataset, and the article leaves this aspect of foreign aid's influence for future research.

The methodology is based on the works of Bandyopadhyay et al. (2013) and Hansen et al. (2009) in advancing the deconstruction of foreign aid from the former article, its control variables specification, and estimation procedure from the latter one. As for the model itself, the main specification follows Hansen et al. (2009) in removing the fixed effects from each country to account for the country-specific characteristics.

The article shows that both forms of aid are characterized by a significant nonlinear relationship with inequality. At low inflow-to-GDP ratios, grants are inequality-reducing, but become inequality-enhancing after a point. Then the relationship reverses itself for grants. One may argue that these relationships may partially cancel each other out. So as a way of verifying the economic significance of the article's findings, a model of the total aid's influence on inequality is also presented. The model shows that foreign aid has a significant, albeit small, negative impact on consumption inequality. As a final form of a check for robustness, the article breaks down the effects of foreign aid depending on the country's GDP per capita. The data are split into four quantiles and the effects of aid on inequality are studied for each of these groups. The relationships remain significant for the most part, but such a breakdown illustrates the complexity of aid's effect on inequality. As for the variable of episodes of violent regime change, it is shown to be insignificant in all of the models independent of the specification. One may conclude that this is most likely due to the missing country-year data during the years when the overthrow was occurring.

The article's structure consists of section 2 reviewing the current and historical literature on the subject of the foreign aid's effect, section 3 describing the methodology and the econometric model that is going to be run, section 4 describing the data, section 5 discussing the results of the estimations, and section 6 presenting conclusions and policy implications.

\section{LITERATURE REVIEW}

Overall, the literature on the economic effect of foreign aid can be divided into four methodological generations. The first generation is concentrated on simple Keynesian Harrod-Domar-like models, which linked foreign aid to economic growth via aid's link to savings and consumption. The second generation started in the 1970s and concentrated on the direct effect of foreign aid on the investment. The third generation of studies began in 1996 with Peter Boone's paper, "Politics and the effectiveness of foreign aid", which was the first to develop aid models with the variables of institutional and policy environments. The fourth generation of research moved away from the growth theory and concentrated on the effects of foreign aid on social factors, such as health, education, etc.

The first models describing the influence of foreign aid on the economy were developed in the 1960s and concentrated mostly on the added productivity of international assistance. These models assumed that every dollar of foreign inflows in the form of assistance should be followed by a one-dollar increase in investment and imports (Rosenstein-Rodan, 1961). Further models got more complicated - the assumption of the fixed capital-output ratio was forgone, while a country's import capacity, as well as domestic savings, were included (Chenery and Carter, 1973). All of these models assumed that aid inflows added to local investment and imports, dollar for dollar.

The third wave of aid research began in 1996 with the abovementioned paper by Peter Boone. This paper is 
revolutionary in the sense that it was the first to address the range of factors that may affect the effectiveness of foreign aid (e.g. political regime) (Boone, 1996).

The latter course of foreign aid literature strayed from looking into the direct effect of foreign aid on growth. Instead, these papers investigated the consequences of the inflow of foreign assistance on social indicators. Some of the most prominent examples of the literature from this period include Burnside and Dollar (1998), who link foreign aid to infant mortality and conclude that when a country has fixed property rights, open trade regimes, and macroeconomic stability, the assistance serves to reduce infant mortality. Collier and Dollar (2001) develop a poverty reduction model showing that aid can only be effective in reducing poverty in an appropriate policy environment. Fielding et al. (2006) show that foreign aid has a positive effect on development outcomes, including health, education, and fertility.

The first studies that link foreign aid to income inequality appear in this period. One of the most prominent papers written in this period was Chong et al. (2009). In this paper, the authors argue that using a simple cross-sectional estimation when evaluating the effect of foreign aid leads to the bias of the estimators due to the problems of simultaneity and reverse causality. The solution proposed is the use of dynamic panel data modeling. The particularity of the effect of foreign aid on income inequality is the presence of autoregressive errors, implying the need to use an estimator with uncorrelated disturbances. Taking this into account, the authors used the GMM-IV model. It showed that when the quality of a country's institutions is taken into account, foreign aid has a positive effect on income inequality, albeit not robust. A similar model is used in Pham (2015), though it's a simple GMM. This paper found that foreign aid exhibited an inequality increasing effect, though a small one.

Bourguignon et al. (2009) reach a similar conclusion when looking into the impact of trade and foreign aid on income inequality. While in their model aid is statistically significant, it isn't economically. However, while the effect is small, it is still helpful for the most deprived decile of the population. Following this stream of results, Shafiullah (2011) finds that the variable of foreign aid causes a small reduction in inequality when fixed and random effect models are used to analyze the data.

The other stream criticizes foreign aid, concluding that it may have an inequality increasing effect. Layton and Nielson (2008) show that, depending on the model specification, foreign assistance either enhances the impact on inequality, or an insignificant one. For the estimation, they use the instrumental variable approach to tackle the issue of endogeneity of the relationship between aid and inequality.

Bjørnskov (2010) shows that the interaction term between democracy and foreign aid has a positive effect on the share of income held by the upper quintile of the population. This result holds for democratic societies only, as the effect is negligible in authoritarian ones. These results were later disproven in Hansen et al. (2009), who address the issue of regression models with non-constant partial effects and conclude that foreign assistance has no significant impact on income inequality.

Another approach to the problem can be seen in Herzer and Nunnenkamp (2012), who argue that foreign aid and income inequality are cointegrated in the same order.
Hence, a panel cointegration model can be built. This model shows that foreign aid exhibits an adverse effect on the distribution of income.

Another type of debate that exists in foreign aid literature concerns the ambiguity of its effect on the economy depending on the kind of aid. These debates originate in the report of the International Financial Institution Advisory Commission in 2000. This report argued that international grants were the preferred instrument for alleviating poverty in developing countries as opposed to loans. Somewhat repeating the argument of Mosley et. al (1987), the report concludes that when the loans given by the IMF and the World Bank are in the hands of the politicians of developing countries, the funds are typically spent on policies that can hardly be called growth-inducing (e.g., tax-reduction) (IFIAC, 2000).

Grants were viewed as preferable to loans based on three main arguments. Firstly, grants are more suited for social projects such as the development of the education or healthcare infrastructure, as they do not produce the returns needed to return the loan in the short run. Secondly, grants do not place more of a debt burden on the developing countries as loans do. Lastly, as grants do not need to be repaid, the donors can place more control on how the funds are spent to uphold the requirements of the UN's development goals and prevent the recipients' governments from squandering the assets, Sanford (2002)

Bulow and Rogoff (2005) reach a similar conclusion as they find that borrowing from development banks encourages more lending by the developing countries, which ultimately retards development.

On the other hand, one can find persuasive arguments regarding why loans should be preferred to grants. The core of this argument lies in the aid's influence on the fiscal behavior of the recipient: unlike loans, grants do not need to be repaid and hence may induce inefficient spending of the funds. Gupta et al. (2004) build a panel model investigating the fiscal response to decomposed aid inflows. The model shows that loans have a positive effect on tax revenues, while grants' impact is negative. This relationship may imply that grants cause inefficient policymaking. In the limited sample of highly corrupt countries, grants were fully offset by a decrease in tax revenues.

These results were later criticized by Morrissey et al. (2006), who show that when long-run effects are considered, this relationship disappears. Their findings suggest that there should be no consistent long-run relationship between decomposed foreign aid and tax revenues. Bandyopadhyay et al. (2013), on the other hand, show that the relationship is not as straightforward. In their paper, they examine a nonlinear relationship between economic growth and foreign aid. Using the quadratic links and modeling simultaneous effects of both loans and grants, they find that grants are better for growth on the low levels of funding as the relationship between growth and financing via grants is hump-shaped. Furthermore, the relationship between growth and loans tends to be U-shaped, implying that high-level loans are highly effective in assisting with a country's growth.

As for the more recent literature, Fiala (2018) finds that when comparing the effect of microfinancing via loans and grants in Uganda, only loans increase the sales of a firm. These findings imply that when faced with the condition of repayment, entrepreneurs allocate their investments more efficiently. 
The current article contributes to the literature by exploring the effects of aid, both constrained and unconstrained by repayment. It also introduces the variable of violent regime changes to eliminate the potential bias on the variable of foreign aid. Lastly, it splits the dataset into four quantiles to explore the relationship between grants, loans, and consumption inequality depending on the country's GDP per capita. This paper takes inspiration from the models presented by Bandyopadhyay et al. (2013) and Hansen et al. (2009) by joining some elements of their models (i.e., the aid deconstruction and estimation methodology) and extending them.

\section{METHODOLOGY}

The article estimates a model of the simultaneous influence of each type of aid following the methodology of Bandyopadhyay et al. (2013). The specification of the empirical model and the estimation method is similar to Hansen et al. (2009).

$$
\begin{aligned}
& \text { GINI }_{i}^{t+1}=\beta_{0}+\beta_{1} * \operatorname{Loan}_{i}^{t} \\
+ & \beta_{2} *\left(\operatorname{Loan}^{2}\right)_{i}^{t}+\beta_{3} * \operatorname{Grant}_{i}^{t} \\
+ & \beta_{4} *\left(\text { Grant }^{2}\right)_{i}^{t}+\beta_{5} \operatorname{Coup}_{i}^{t} \\
+ & \beta_{6} \text { Polity }_{i}^{t}+\beta_{j} X_{i}^{t}+\mu_{i}+\varepsilon_{i}^{t}
\end{aligned}
$$

In this specification, GINI is the consumption-based income inequality index, while Loan and Grant are the variables of the international assistance provided with and without the constraint of returning the money respectively. The Loan and Grant are expressed in relative terms as the percentage of real GDP in 2016 USD. This is done to normalize the amounts of aid between the countries in the sample. As the countries in the sample differ in the sizes of their economies, populations, and territories, the mode estimated on absolute values would be flawed. The issue would be caused by neglecting the relative importance of the assistance for the country's economy, which can be eliminated with the use of relative measures.

I use consumption as a measure of inequality because traditional income inequality measures do not reflect the asset availability of the population (e.g., housing), while this is reflected in the consumption inequality measure. The other issue with income as the primary measure of inequality is that it ignores the shadow economy - the income of the people on the bottom of the income distribution is often underreported in developing countries for the sake of tax evasion, making the income inequality measure imperfect. It is worth noting that the income measure is used in the robustness check portion of the article.

Polity is the Polity IV index created by Center for Systemic peace; it ranges from -10 to 10 , and is determined by the country's overall level of democracy, press freedom, transparency of the governing bodies, and the general process of electing of the government.

The Coup is an indicator of a violent political regime change. This variable is expected to have a significant effect on the model's structure as it was shown to influence the aid variable and the inequality variable. Its influence on the foreign aid is negative and proven by the literature (Masaki, 2016, Haggard and Kaufman, 2012). As for the impact on regime changes, it's positive but not as straightforward.
According to the literature, the relationship is backward income inequality causes regime changes. The variable of regime changes concerns the coup d'etat's influence on income inequality. If one supposes that regimes become more egalitarian after change, the income inequality should decline (Galbraith 2010). However, it is expected that a period of political instability would come after the overthrow, hence causing a decrease in equality. Understandably, this relationship is not straightforward and should be explored in depth. But since it's not our variable of interest and is only added to the model to eliminate a part of the bias, it shouldn't matter all that much.

The problem with the Coup variable, however, is that the episodes of violent regime change usually cause abrupt breaks in the data. This trend is especially evident in the 1970s-1980s, which were historically characterized by many coup d'etats. But unfortunately, the data for the response variable and independent ones is not available for these years. This issue is not supposed to cause much trouble. Most of the time, the indicator is positive for a year after the coup ends, and hence, matches the existing data. The dummy at the end of such structural breaks should be enough to soften the impact of the breaks.

The control variables are standard for the income inequality literature such as Burnside and Dollar (1998), Hansen and Tarp (2000) Arndt et al. (2010). The set of control variables includes the index of human capital, trade openness, the share of government expenditures of GDP and the share of population living in rural areas.

As suggested by Shafiullah (2011), all variables are taken with a lag of one year as it is expected that the foreign assistance's effect will not be immediate. As a way of checking the robustness of the findings, models with threeand five-year lags are also estimated. The lag also alleviates a potential endogeneity problem. While foreign aid affects income inequality, the reverse can also be true. Hence, by forwarding the response variable by one-year, we may limit its effect as inequality in the future period is quite unlikely to have a significant influence on the amount of foreign aid in the present one. Including $\mu$ I further control for unobserved individual country effects, while $\varepsilon$ denotes the error term.

\section{DATA}

The inequality measure is taken from the Global Consumption and Income Project (GCIP), which presents a dataset containing measures of inequality based on income and consumption spanning 1960-2015 and covering more than 160 countries. This dataset was chosen over the other inequality datasets (WIID, SWIID, EHII, etc.) due to its countryyear coverage. As it covers more country-years, it allows running models on more observations. While the merged datasets for the other income inequality measures allowed running the final regression on a mere amount of 400-600 observations, the GCIP allows for almost 3,000 observations in the merged dataset (this is especially helpful considering that the independent variables are estimated with a lag, which already reduces the number of observations by a large margin).

The data for the dependent variable of international loans and grants are taken from the OECD's Geographical Distribution of Financial Flows to Developing Countries annual publication. The full dataset covers over 150 different countries during 1960-2018. It contains the data on all of the 
aid funds flowing into the developing countries from both country and supra-national level donors. The final model uses the measure of net loans instead of gross loans because net loans more accurately show how much aid money the country has at a given moment. This choice may also capture the effects of political violence more accurately (i.e., states are more likely to receive a loan after a government overthrow and less likely to return old loans (Haggard and Kaufman, 2012), as well as partially serve as an indicator for the quality of governance in the country.

To measure the level of democracy in the country, the model uses the Polity index from Polity IV Annual time series covering 167 countries from 1800-2017. Polity IV is a combined index consisting of indices measuring democracy and autocracy. They are constructed using the measures of the governance selection process and its openness, regulation of the participation in political processes, etc. The Polity IV index ranges from -10 to 10 , depending on the level of the democracy in the country. The index was normalized to the range of 0 to 20 during the process of data preparation.

To account for the possible structural breaks in the inequality distribution, the data on the adverse political regime changes are taken from the PITF State Failure Problem Set. It covers episodes of regime changes in 85 countries from 1955 to 2017.

Other control variables should also be added to the model to reduce the endogeneity. These variables include the index of human capital that is based on years of study taken from Barro and Lee (2013) and the assumed rate of return to education, which is calculated using the Mincer equation Psacharopoulos (1994); trade openness measured as the ratio of exports and imports to GDP; and government expenditures as the share of GDP. The data for human capital, trade openness, and government expenditures are taken from Penn World Tables (Feenstra et al., 2015), while the data on the rural share of the population can be found in World Development Indicators. Some additional dummy controls are added: the continent of the origin country, and whether the state is a post-Soviet one.

As one can see from Table 1, grants are far more preferable to loans when it comes to foreign aid. Judging by the averages, the total quantity of loans is more than three times smaller than the grants given by the international community. These data are presented for net loans, but even if we consider gross loans, the grants are still twice as large as the loans (see Figure 2).

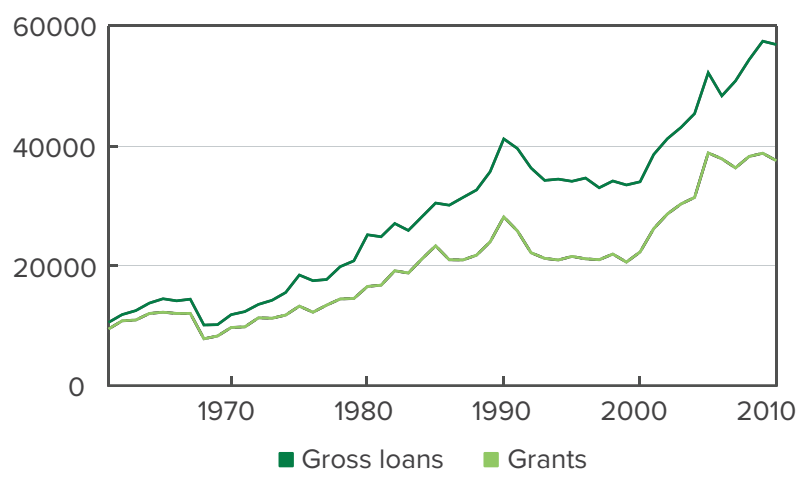

Figure 2. Total Yearly Aid Inflows in 2016 USD
With this in mind, we can construct simple classifications for the countries in the sample to see whether there is a strict divide in the funding source specialization. Considering the relative weight of grants versus loans, one can view the country as loan-oriented if the relative importance of loans is higher than grants. The country is deemed to be grant-oriented if grants account for more than twice the percentage of loans in the economy. We end up having six states that are purely loan-oriented and 57 countries that are grant-oriented, with the rest falling somewhere in between (the full lists can be found in Appendix A2). The traditional role of loans in the loan-oriented countries of the sample cannot be overestimated, and it may have led to positive inequality outcomes. Some of those countries were allowed to take large amounts of loans due to the U.S.-sponsored regimes during the '70s and '80s (e.g., Chile, Indonesia). Others are countries that have historically been productive in the poverty-alleviation process (e.g., India, Turkey). Historical development of these countries and the growth associated with poverty reduction may become a focus of further research.

Some other interesting facts that can be derived from Table 1 include the importance of the government sector in developing economies. The role of government expenditures in the budget averages out to approximately $18 \%$. A few African countries are most likely the cause of the high maximum value of the variable (mostly Nigeria and Madagascar).

Most of the countries in the sample are open economies and are considered to be

quite democratic, according to the polity index and their large rural population. The high rural population isn't driven by the outliers, but by the inclusion of data for developing countries during the 1960s and 1970s. The other side of the distribution is exclusively produced by the data on Singapore.

As for the variable of violent political regime changes, it is only present in less than $3 \%$ of the sample. This is mostly due to coups being a rare political event and the unavailability of the data for the years in which the overthrow has occurred. This may cause further problems in the estimation stage of the article.

After merging the data, we end up with the dataset containing 2,994 observations during 1961-2010 and in 75 countries, with all of the countries with less than four countryyear cells deleted. One of the peculiarities of the merged

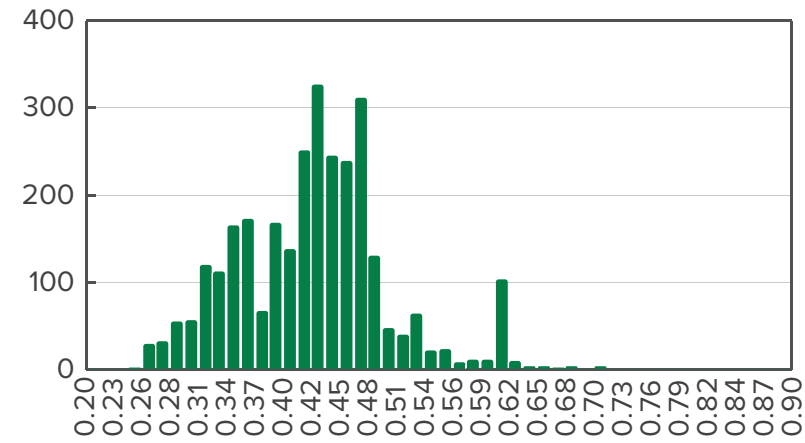

Figure 3. The Boxplot of Consumption Inequality 
data is the presence of Singapore and Israel in the final sample. To avoid any inconsistencies with the data that may have arisen due to the presence of these countries in the sample, both countries were excluded from the final models.

Figure 3 presents the distribution of income inequality (consumption estimate). As one can observe the inequality has remained stable over the entire available period, though this might be explained by the composition of the sample (i.e., only developing countries are selected and China is out of the sample).

Initially, the variables of loans and grants were characterized by outliers that skewed both distributions. To normalize them, the outliers have been dropped. As a result, the sample has been reduced to 2,887 observations.

\section{RESULTS}

The following section is structured in the following way: the first subsection presents an overview of the estimation results of the primary model, the second subsection is dedicated to robustness checks of the models, and the last subsection is dedicated to the post-estimation tests.

\subsection{The Main Results}

As expected, both loans and grants have significant effects on income inequality in the final FE (fixed effects) model. However, the direction of their impact seems to be the opposite. For loans, the breakpoint at which they help to reduce inequality is $2.6 \%$ of GDP. This percentage of loans was at some point present in $33.3 \%$ of the countries in the sample. As for the grants, the breakpoint after which they start to enhance the inequality is $9.1 \%$. It is quite interesting to note that the amount of grants at which they are helpful for the economy is quite significant in relative terms. This percentage was at one point present in $20 \%$ of the countries of the sample.

As for the violent episodes of political change, they don't seem to affect income inequality despite being one of the main reasons behind government overthrows. This insignificance may be due to the structural breaks in the data, which distort the results. Some ways of dealing with this issue are presented in the final chapter.

The coefficients on all the other control variables are consistent with the literature. Human capital, trade openness, the percentage of the rural population, and government expenditures all have an inequality enhancing effect, while the polity index shows reduced inequality, as was shown in Hansen et al. (2009). The full model can be found in Table 4.

\subsection{Robustness Check}

Table 5 presents the first robustness check of the model. The main claim behind the one-year lags in our main model is that the changes in inequality are not visible as soon as aid is given. We take the minimal lag following the suggestion presented in Shafiullah (2011), but one may argue that a oneyear lag is too short. Sometimes, goverments in developing countries take years to invest funds. So to test for this, we take lags of three and five years to test the model's robustness.
It appears that grants affect income inequality in neither the 3rd nor 5th lag models. On the other hand, loans have a significant adverse effect on the third lag with a consistent non-linear relationship. That suggests they have a lasting impact on a country's economy and are essential to reducing inequality long after they came into the country. However, the effect of loans becomes insignificant with the fifth lag model, which suggests that the positive influence of this form of aid diffuses after some time. As for the coup d'état, it remained insignificant in all of the models above. Hausman test for 3 -year lag model yielded $p$-value of 0.002 , while the same test for 5-year lag yielded the value of 0.0027 , meaning that fixed effects model is appropriate for both specifications.

The second robustness check of the model (Table 6) concerns the variable of net loans. As the argument of the article goes: net loans are a preferable measure to gross loans as they show the actual amount of aid that a country has at a given year. But the argument may also apply vice versa - one should look into how much money is given to a country per year to observe the results.

The term of gross loans is insignificant in this specification. This means that the total amount of aid that's pumped into the economy per year doesn't matter for income inequality. Only the real amount available is the value that determines the change in inequality.

Table 7 deals with the economic significance of the model. As the effects of both loans and grants are simultaneous, one may certainly argue that they cancel each other out and the cumulative effect of foreign aid is either insignificant or too small to matter. Table 5 presents the full aid model with the removal of the hump shape hypothesis. As the effects of the decomposed aid are inverse to each other, the U-shaped relationship is unlikely to hold. Moreover, the linear relationship is a standard specification for the current literature (Herzer and Nunnenkamp, 2012, Layton and Nielson, 2008, etc.)

The variable of the aid ratio is significant econometrically, though that's not the case economically. The change presented would mean that a $1 \%$ increase in total aid would result in approximately a $0.2 \%$ wealth transfer from the population above the median income to the population below it.

Table 6 deals with the separation of the influence of foreign aid types. The results of models of simultaneous influence may have been caused by the multicollinearity in the loan and grant variables. The following table presents separate models for both grants and loans. The results from this robustness check show that both variables are significant, and their magnitudes and directions of the effect remain virtually unchanged from the main model.

Table 7 is the last of the robustness check section of this chapter. It tests the consistency of the model under a different measurement of inequality. Instead of a consumption-based measure, the models use an income-based one.

The income-based models show results similar to those of the primary model, but less significant. This may be due to the noisiness of the income inequality measure as compared to the consumption inequality one. Both loans and grants still exhibit a significant negative and positive effect on income inequality, respectively. 


\subsection{Post-Estimation Tests}

To see whether the main model has any statistical issues, l've conducted three post-estimation tests for the following issues: multicollinearity, autocorrelation, and heteroskedasticity.

To test for multicollinearity, l've conducted a variance inflation factor test (VIF) with centered values of test's coefficients. The mean-variance inflation factor is 2.91 , meaning that the model isn't characterized by multicollinearity.

The Inoue and Solo LM test was used to test the model for autocorrelation, of any order, with the null hypothesis of there being none. The test produced a $p$-value of 0.936 , so it fails to reject the null hypothesis of the test.

Lastly, to test for heteroskedasticity, I've used a Modified Wald test for group-wise heteroskedasticity. With the nul hypothesis of homoscedasticity, this test has shown a $p$-value of 0 , meaning that one can reject the assumption of homoskedasticity.

To solve this issue, a linear regression was run, absorbing multiple levels of fixed effects with robust standard errors. The panel variable was chosen for the factor whose effects were specified to be absorbed by the model. It is an extension of the linear regression with a large dummy-variable set and is usually used for datasets with multiple levels of fixed effects. This model is preferable to the simple addition of robust standard errors to the fixed effects panel model when it comes to heteroskedasticity. This is due to the fact that it absorbs multiple levels of country-level effects. The results of the model are presented in Table 8.

As one can see, the issue of heteroskedasticity of the data isn't as critical as might seem at first glance. The model with the absorption of country-level fixed effects remains consistent with the article's previous findings in terms of variables' significance.

To test whether the asymmetry effect of GDP does matter I ran regressions for quantile subsamples. Table 9 show the estimation results obtained for the quantile groups, depending on the country's GDP per capita. The full sample were split into the following groups: GDP per capita below USD 1,350 - the 25th percentile, GDP per capita between USD 1,350 and 2,950 - the 50th percentile, GDP per capita between USD 2,950 USD and 6,175 - the 75th percentile, and GDP per capita above USD 6,175. After the split, all countries having less than three observations within a dataset were dropped.

Obtained outcomes show that loans and grants have different effects depending on the GDP per capita for the country. The relationship that we've explored in the earlier models is confirmed for the poorest quantile of our dataset. Both grants and loans are significant, albeit loans are at a 10\% significance level. Here grants have an inequality reducing effect until they reach $9.7 \%$ of a country's GDP, after which they start to increase consumption disparity. Loans show us that, for this particular segment of our dataset, they have an inequality increasing effect until they reach 5.1\% of GDP. After this point, loans reduce inequality.

The results for the second model show us a differing relationship between these variables. In this model, loans have a completely insignificant relationship with consumption inequality, while the relationship for grants is reversed. For these countries, grants have an inequality increasing effect until they reach $10.1 \%$ of GDP. After this point, grants start reducing it.

The third quantile shows similar results with loans being an insignificant factor in determining consumption inequality; however, here the relationship between grants and inequality is reversed once more. Now grants have an inequality reducing effect until they reach $6.6 \%$ of GDP, after which point they increase the consumption disparity in the country.

And for our final quantile, we can see that grants are insignificant for consumption inequality, though loans have a significant linear term. To make sure that what we're seeing is not the result of statistical noise, I've estimated one final model with loans as a linear term. This model shows that the estimated relationship holds true and that, while grants do not affect consumption inequality for these countries, loans are significant and have a considerable effect on consumption inequality. A $1 \%$ increase in the loans-to-GDP ratio will result in approximately a $2 \%$ wealth transfer from people above the median income to people below it.

\section{CONCLUSIONS}

Some important policy implications can be derived from the results above. The first one is that grants and loans are different in their effects on consumption inequality. These relationships may be caused by the difference in the repayment condition of both. As grants don't need to be repaid, the money is going to be used inefficiently because there's no direct incentive to use them properly. The relationship is reverse for loans.

Overall, foreign aid has a positive, albeit small, effect on income inequality. With the correct balance of loans and grants, a net inequality reduction effect can be reached. The last estimation of the previous chapter has shed some light on the differing effects of loans and grants. We have seen that loans work better for the poorest countries in the sample (by reducing their consumption disparity after reaching 5.1\% of GDP), as well as for the richest countries in the sample, by having a linear effect on their consumption inequality. It is worth noting that grants can also help the poorest countries in the sample.

When it comes to the middle of wealth distribution, loans tend to be insignificant and have little to no influence on the inequality, while grants have strong and consistent effects on the dependent variable. Though, it is worth noting that the mechanism behind loans' and grants' differing effects should be studied in depth by researchers further.

Generally speaking, loans are well suited for a reduction in small quantities. A net point of $2 \%$ is needed for the loans to have an inequality-reducing effect. As for grants, they are only harmful when they constitute more than $9 \%$ of the economy, which may seem like a lot. But such values are indeed present in the sample, and they aren't as uncommon as they may appear at the first glance.

The article has shown that the question of the effect of foreign aid on income inequality is an important topic that deserves more attention in the literature than it currently gets. 
Not only is income inequality a more appropriate measure of effectiveness when it comes to the alleviation of poverty, but it also helps to see what is the effect of international efforts to combat global poverty.

The decomposition of the aid sheds light on the mechanism behind its influence on the economy. In this regard, the article has shown that the effect is twofold - one form of assistance serves as an inequality redactor, while another kind is an inequality expander. This relationship is shown to be non-linear with its breakpoints and the appropriate strategies for each type of aid.

The model has passed most forms of the robustness check, though it is worth noting that loans were more consistent than grants. This result may have been due to how the loans were measured. In the models above, a measure of net loans was used. As such, it may have captured some degree of political confidence of government bodies, and caused the coefficient to be more stable over time.

Still, the research is just one small step on the way to fully understanding the nature of aid's influence on income inequality. Another avenue that may be studied in the future is further deconstruction of the loan variable into loans that are given on the condition of legislative reforms and loans that are given on the simple term of repayment. This may show an even more interesting result as reform-demanding loans are likely to have a larger magnitude of their effect on the inequality.

As for the variable of political violence, it was insignificant in all of our models. In further research, it may be worth focusing on an alternative measure of the political instability within countries. One of such indicators may be the percentage of the population fleeing the country as refugees or the rate of Internally Displaced Persons (IDP) in society. These ratios are likely to be correlated with both income inequality and the amount of foreign aid given to a country. Moreover, because the variable of coups was only binary, it has had a significant flaw in that it ignores the magnitude of the political violence in the country. The number of refugees is a lot more sensitive, and their emergence is more common, than the episodes of political overthrows, hence making it a better potential indicator. 


\section{REFERENCES}

Aghion, P., Bolton, P. (1997). A theory of trickle-down growth and development. The Review of Economic Studies, 64(2), 151-172. https://doi.org/10.2307/2971707

Alesina, A., Rodrik, D. (1994). Distributive politics and economic growth. The Quarterly Journal of Economics, 109(2), 465-490. https://doi.org/10.2307/2118470

Arndt, C., Jones, S., Tarp, F. (2010). Aid, growth, and development have we come full circle? WIDER Working Paper Series, 96. Helsinki: UNU-WIDER. Retrieved from https://www.wider.unu.edu/sites/default/files/wp2010-96.pdf

Bandyopadhyay, S., Lahiri, S., Younas, J. (2013). Financing growth: foreign aid vs. foreign loans: nonlinearities and complementarities. Working Paper Series, 2013-031A St. Louis: Federal Reserve Bank of St. Louis. https://doi. org/10.20955/wp.2013.031

Barro, R. J., Lee, J. W. (2013). A new data set of educational attainment in the world, 1950-2010. Journal of Development Economics, 104, 184-198. https://doi.org/10.3386/w15902

Basu, K., Stiglitz, J. E. (2016). Inequality and growth: Patterns and policy. Concepts and Analysis, 1. International Economic Association Series. Palgrave Macmillan. http://hdl. handle.net/10986/24983

Bjørnskov, C. (2009). Do elites benefit from democracy and foreign aid in developing countries? Journal of Development Economics, 92(2), 115-124. https://doi. org/10.1016/j.jdeveco.2009.03.001

Boone, P. (1996). Politics and the effectiveness of foreign aid. European Economic Review, 40(2), 289-329. https://doi. org/10.1016/0014-2921(95)00127-1

Bourguignon, F., Levin, V., Rosenblatt, D. (2009) International redistribution of income. World Development, 37(1), 1-10. https://doi.org/10.1016/j.worlddev.2008.06.008

Bulow, J., Rogoff, K. (2005). Grants versus loans for development banks. American Economic Review, 95(2), 393-397. https://doi.org/10.1257/000282805774669727

Burnside, A. C., Dollar, D. (1998). Aid, the incentive regime, and poverty reduction. World Bank Policy Research Working Paper, 1937.

Chani, M. I., Jan, S. A., Pervaiz, Z., Chaudhary, A. R. (2014). Human capital inequality and income inequality: testing for causality. Quality \& Quantity: International Journal of Methodology, 48(1), 149-156. https://doi.org/10.1007/s11135012-9755-7

Chenery, H. B., Carter, N. G. (1973). Foreign assistance and development performance, 1960-1970. The American Economic Review, 63(2), 459-468. https://www.jstor.org/ stable/1817109

Chong, A., Gradstein, M., Calderon, C. (2009). Can foreign aid reduce income inequality and poverty? Public Choice, 140(1), 59-84. https://doi.org/10.1007/s11127-009-9412-4

Collier, P., Dollar, D. (2001). Can the world cut poverty in half? How policy reform and effective aid can meet international development goals. World Development, 29(11), 1787-1802. https://doi.org/10.1016/S0305-750X(01)00076-6
Feenstra, R., Inklaar, R., Timmer, M. P. (2015). The next generation of the Penn World Table. American Economic Review, 105(10), 3150-3182. https://doi.org/10.1257/ aer.20130954

Fiala, N. (2018). Returns to microcredit, cash grants, and training for male and female microentrepreneurs in Uganda. World Development, 105(C), 189-200. https://doi. org/10.1016/j.worlddev.2017.12.027

Fielding, D., McGillivray, M., Torres, S. (2006). A wider approach to aid effectiveness: Correlated impacts on health, wealth, fertility, and education. WIDER Working Paper Series, 023. http://hdl.handle.net/10419/63372

Galbraith, J. K. (2010). Inequality and economic and political change: a comparative perspective. Cambridge Journal of Regions, Economy and Society, 4(1), 13-27. https://doi.org/10.1093/cjres/rsq014

Gupta, S., Clements, B., Pivovarsky, A., Tiongson, E. (2004). Foreign aid and revenue response: Does the composition of aid matter? in Helping Countries Develop: The Role of Fiscal Policy by S. Gupta, B. Clements G. Inchauste, 385-406. Washington DC: International Monetary Fund.

Haggard, S., Kaufman, R. R. (2012). Inequality and regime change: Democratic transitions and the stability of democratic rule. American Political Science Review, 106(3), 495-516. https://doi.org/10.1017/S0003055412000287

Hansen, H., Tarp, F. (2000). Aid effectiveness disputed. Journal of International Development, 12(3). https://doi. org/10.1002/(SICl)1099-1328(200004)12:3<375::AIDJID657>3.0.CO;2-M

Hansen, H., Rants, L. L., Buhl-Wiggers, J. (2009). Do elites benefit from democracy and foreign aid in developing countries?: Comment. CREDIT Research Paper, 9(6). Nottingham: Centre for Research in Economic Development and International Trade. Retrieved from https://www. nottingham.ac.uk/credit/documents/papers/09-06.pdf

Herzer, D., Nunnenkamp, P. (2012). The effect of foreign aid on income inequality: Evidence from panel cointegration. Kiel Working Papers, 1762. Kiel: Kiel Institute for the World Economy (IfW). http://hdl.handle.net/10419/56382

Houle, C. (2016). Why class inequality breeds coups but not civil wars. Journal of Peace Research, 53(5), 680-695. https://doi.org/10.1177/0022343316652187

IFIAC. (2000). International financial institutions reform: report of the International Financial Institution Advisory Commission. Washington DC.

Keeley, B. (2012). From aid to development: The global fight against poverty. Paris: OECD Publishing.

Layton, T., Nielson, D. (2008). Aiding inequality: The effect of foreign aid on income inequality. Brigham Young University.

Lee, J.-W., Lee, H. (2018). Human capital and income inequality. ADBI Working Papers, 810. Japan: Asian Development Bank Institute. Retrieved from https://www. adb.org/publications/human-capital-and-income-inequality 
Masaki, T. (2016). Coups d'etat and foreign Aid. World Development, 79, 51-68. https://doi.org/10.1016/j. worlddev.2015.11.004

Morrissey, O., Islei, O., M'Amanja, D. (2006). Aid loans versus aid grants: Are the effects different? CREDIT Research Paper, 06/07. Nottingham: Centre for Research in Economic Development and International Trade.

Mosley, P., Hudson, J., Horrell, S. (1987). Aid, the public sector and the market in less developed countries. The Economic Journal, 97(387), 616-641. https://doi. org/10.2307/2232927

OECD. (2006). Promoting pro-poor growth. Key Policy Messages. Paris: Organisation for Economic Co-operation and Development. Retrieved from https://www.oecd.org/ greengrowth/green-development/43514554.pdf

Pham, T. H. H. (2015). Income inequality and foreign aid. Working Papers, hal-01158240. https://hal.archives-ouvertes. $\mathrm{fr} / \mathrm{hal}-01158240$

Piketty, T., Saez, E. (2003). Income inequality in the United States, 1913-1998. The Quarterly Journal of Economics, 118(1), 1-41. https://doi.org/10.1162/00335530360535135

Psacharopoulos, G. (1994). Returns to investment in education: A global update. World Development, 22(9), 1325-1343. https://doi.org/10.1016/0305-750X(94)90007-8
Ravallion, M. (2014). Income inequality in the developing world. Science, 344, 6186, 851-855. https://doi.org/10.1126/ science. 1251875

Rosenstein-Rodan, P. N. (1961). International aid for underdeveloped countries. Review of Economics and Statistics, 43(2), 107-138. https://doi.org/10.2307/1928662

Sanford, J. E. (2002). World Bank: IDA loans or IDA grants? World Development, 30(5), 741-762. https://doi. org/10.1016/S0305-750X(02)00003-7

Shafiullah, M. (2011). Foreign aid and its impact on income inequality. International Review of Business Research Papers, 7(2), 91-105.

Stiglitz, J. E. (2012). The Price of Inequality: How Today's Divided Society Endangers Our Future. New York: W. W. Norton \& Company.

UN. (2005). The millennium development goals. Progress Report. New York: United Nations. Retrieved from https://unstats.un.org/unsd/mi/pdf/MDG\%20Book.pdf

World Bank. (2006). Equity and development. World Development Report. New York: The World Bank and Oxford University Press. Retrieved from http://documents1. worldbank.org/curated/en/435331468127174418/pdf/32204 OWorldODevelopmentOReport02006.pdf 
TABLES

Table 1. Summary Statistics

\begin{tabular}{l|c|c|c|c|c}
\hline Variable & Observations & Mean & $\begin{array}{c}\text { Standard } \\
\text { deviation }\end{array}$ & Min & Max \\
\hline Grants & 2,994 & 0.017 & 0.024 & 0.000 & 0.181 \\
\hline Net loans & 2,994 & 0.005 & 0.010 & -0.048 & 0.171 \\
\hline GINI & 2,994 & 0.425 & 0.077 & 0.247 & 0.875 \\
\hline Human capital & 2,994 & 1.732 & 0.538 & 1.007 & 3.301 \\
\hline Govt. spending & 2,994 & 0.178 & 0.089 & 0.016 & 0.687 \\
\hline Polity & 2,994 & 0.538 & 6.874 & -10.000 & 10.000 \\
\hline Trade openness & 2,994 & 63.352 & 39.337 & 5.222 & 251.112 \\
\hline Rural pop. & 2,994 & 0.598 & 0.218 & 0.000 & 0.978 \\
\hline Coup d'etat & 2,994 & 0.026 & 0.159 & 0.000 & 1.000 \\
\hline
\end{tabular}


Table 2. Foreign Assistance and Consumption Inequality: Estimation Results

\begin{tabular}{|c|c|c|c|c|}
\hline GINI & $\mathrm{RE}$ & $\mathrm{RE}$ & RE & FE \\
\hline & (1) & $(2)$ & (3) & (4) \\
\hline Loans & $\begin{array}{c}0.2838^{* * *} \\
(0.006)\end{array}$ & $\begin{array}{l}0.3191^{* * *} \\
(0.002)\end{array}$ & $\begin{array}{c}0.3341^{* * *} \\
(0.002)\end{array}$ & $\begin{array}{c}0.3362^{* * *} \\
(0.001)\end{array}$ \\
\hline Loans $^{2}$ & $\begin{array}{c}-5.6236^{* * *} \\
(0.004)\end{array}$ & $\begin{array}{c}-6.1574^{* * *} \\
(0.002)\end{array}$ & $\begin{array}{c}-6.2562^{* * *} \\
(0.001)\end{array}$ & $\begin{array}{c}-6.3039^{* * *} \\
(0.001)\end{array}$ \\
\hline Grants & $\begin{array}{c}-0.3997^{* * *} \\
(0.000)\end{array}$ & $\begin{array}{c}-0.2989^{* * *} \\
(0.003)\end{array}$ & $\begin{array}{c}-0.3195^{* * *} \\
(0.002)\end{array}$ & $\begin{array}{c}-0.3201^{* * *} \\
(0.002)\end{array}$ \\
\hline Grants $^{2}$ & & $\begin{array}{l}1.6150^{* *} \\
(0.025)\end{array}$ & $\begin{array}{c}1.7534^{* *} \\
(0.015)\end{array}$ & $\begin{array}{c}1.7509^{* *} \\
(0.015)\end{array}$ \\
\hline Openness & & $\begin{array}{c}0.0071^{* * *} \\
(0.001)\end{array}$ & $\begin{array}{c}0.0067^{* * *} \\
(0.002)\end{array}$ & $\begin{array}{c}0.0068^{* * *} \\
(0.002)\end{array}$ \\
\hline Govt. exp. & & $\begin{array}{c}0.0614^{* * *} \\
(0.000)\end{array}$ & $\begin{array}{c}0.0634^{* * *} \\
(0.000)\end{array}$ & $\begin{array}{c}0.0633^{* * *} \\
(0.000)\end{array}$ \\
\hline Human cap. & & $\begin{array}{c}0.0166^{* * *} \\
(0.000)\end{array}$ & $\begin{array}{c}0.0217^{* * *} \\
(0.000)\end{array}$ & $\begin{array}{c}0.0215^{* * *} \\
(0.000)\end{array}$ \\
\hline Polity & & $\begin{array}{c}-0.0004^{* * *} \\
(0.006)\end{array}$ & $\begin{array}{c}-0.0004^{* * *} \\
(0.006)\end{array}$ & $\begin{array}{c}-0.0004^{* * *} \\
(0.005)\end{array}$ \\
\hline Rural pop. & & $\begin{array}{l}0.0247^{*} \\
(0.089)\end{array}$ & $\begin{array}{c}0.0377^{* *} \\
(0.010)\end{array}$ & $\begin{array}{c}0.0375^{* *} \\
(0.012)\end{array}$ \\
\hline Coup d'état & & $\begin{array}{r}-0.0012 \\
(0.768)\end{array}$ & $\begin{array}{r}-0.0010 \\
(0.790)\end{array}$ & $\begin{array}{r}-0.0012 \\
(0.767)\end{array}$ \\
\hline Americas & & & $\begin{array}{l}0.0024 \\
(0.896)\end{array}$ & \\
\hline Asia & & & $\begin{array}{c}-0.1091^{* * *} \\
(0.000)\end{array}$ & \\
\hline Europe & & & $\begin{array}{c}-0.1809^{* * *} \\
(0.000)\end{array}$ & \\
\hline Middle East & & & $\begin{array}{c}-0.0490 \\
(0.283)\end{array}$ & \\
\hline Oceania & & & $\begin{array}{l}-0.1102^{*} \\
(0.083)\end{array}$ & \\
\hline Post-Soviet & & & $\begin{array}{c}-0.1748^{* * *} \\
(0.000)\end{array}$ & \\
\hline $\begin{array}{l}\text { Hausman }\left(\chi^{2}\right) \\
N\end{array}$ & 2,887 & 2,887 & 2,887 & $\begin{array}{c}31.29^{* * *} \\
2,887\end{array}$ \\
\hline
\end{tabular}

$p$-values in parentheses ${ }^{*} p<0.1 ;{ }^{* *} p<0.05 ; \quad ;<0.01$ 
Table 3. Foreign Assistance and Consumption Inequality: Time Effect

\begin{tabular}{|c|c|c|c|c|}
\hline \multirow{2}{*}{ GINI } & \multicolumn{2}{|c|}{3 year lag } & \multicolumn{2}{|c|}{5 year lag } \\
\hline & $\mathrm{RE}$ & $\mathrm{FE}$ & $\mathrm{RE}$ & FE \\
\hline & (1) & (2) & (3) & (4) \\
\hline Loans & $\begin{array}{c}0.2631^{* *} \\
(0.018)\end{array}$ & $\begin{array}{c}0.2666^{* *} \\
(0.017)\end{array}$ & $\begin{array}{l}0.1289 \\
(0.277)\end{array}$ & $\begin{array}{l}0.1326 \\
(0.262)\end{array}$ \\
\hline Loans $^{2}$ & $\begin{array}{c}-4.6402^{* *} \\
(0.021)\end{array}$ & $\begin{array}{c}-4.7189^{* *} \\
(0.019)\end{array}$ & $\begin{array}{c}-3.2510 \\
(0.121)\end{array}$ & $\begin{array}{c}-3.3458 \\
(0.111)\end{array}$ \\
\hline Grants & $\begin{array}{c}-0.1659 \\
(0.112)\end{array}$ & $\begin{array}{l}-0.1617 \\
(0.122)\end{array}$ & $\begin{array}{c}-0.0119 \\
(0.911)\end{array}$ & $\begin{array}{c}-0.0058 \\
(0.957)\end{array}$ \\
\hline Grants $^{2}$ & $\begin{array}{l}0.6102 \\
(0.418)\end{array}$ & $\begin{array}{l}0.5787 \\
(0.444)\end{array}$ & $\begin{array}{l}-0.0140 \\
(0.985)\end{array}$ & $\begin{array}{l}-0.0610 \\
(0.936)\end{array}$ \\
\hline Openness & $\begin{array}{c}0.0086^{* * *} \\
(0.000)\end{array}$ & $\begin{array}{c}0.0088^{* * *} \\
(0.000)\end{array}$ & $\begin{array}{c}0.0100^{* * *} \\
(0.000)\end{array}$ & $\begin{array}{c}0.0102^{* * *} \\
(0.000)\end{array}$ \\
\hline Govt. exp. & $\begin{array}{c}0.0748^{* * *} \\
(0.000)\end{array}$ & $\begin{array}{c}0.0748^{* * *} \\
(0.000)\end{array}$ & $\begin{array}{c}0.0861^{* * *} \\
(0.000)\end{array}$ & $\begin{array}{c}0.0862^{* * *} \\
(0.000)\end{array}$ \\
\hline Human cap. & $\begin{array}{c}0.0234^{* * *} \\
(0.000)\end{array}$ & $\begin{array}{c}0.0233^{* * *} \\
(0.000)\end{array}$ & $\begin{array}{c}0.0241^{* * *} \\
(0.000)\end{array}$ & $\begin{array}{c}0.0240^{* * *} \\
(0.000)\end{array}$ \\
\hline Polity & $\begin{array}{c}-0.0005^{* * *} \\
(0.001)\end{array}$ & $\begin{array}{c}-0.0005^{* * *} \\
(0.001)\end{array}$ & $\begin{array}{c}-0.0006^{* * *} \\
(0.000)\end{array}$ & $\begin{array}{c}-0.0006^{* * *} \\
(0.000)\end{array}$ \\
\hline Rural pop. & $\begin{array}{c}0.0472^{* * *} \\
(0.002)\end{array}$ & $\begin{array}{c}0.0478^{* * *} \\
(0.002)\end{array}$ & $\begin{array}{c}0.0527^{* * *} \\
(0.001)\end{array}$ & $\begin{array}{c}0.0539^{* * *} \\
(0.001)\end{array}$ \\
\hline Coup d'état & $\begin{array}{l}-0.0012 \\
(0.765)\end{array}$ & $\begin{array}{c}-0.0013 \\
(0.736)\end{array}$ & $\begin{array}{c}-0.0040 \\
(0.315)\end{array}$ & $\begin{array}{l}-0.0041 \\
(0.297)\end{array}$ \\
\hline Americas & $\begin{array}{l}0.0080 \\
(0.658)\end{array}$ & & $\begin{array}{l}0.0132 \\
(0.484)\end{array}$ & \\
\hline Asia & $\begin{array}{c}-0.1060^{* * *} \\
(0.000)\end{array}$ & & $\begin{array}{c}-0.1020^{* * *} \\
(0.000)\end{array}$ & \\
\hline Europe & $\begin{array}{c}-0.1782^{* * *} \\
(0.000)\end{array}$ & & $\begin{array}{c}-0.1725^{* * *} \\
(0.000)\end{array}$ & \\
\hline Middle East & $\begin{array}{c}-0.0453 \\
(0.317)\end{array}$ & & $\begin{array}{c}-0.0442 \\
(0.344)\end{array}$ & \\
\hline Oceania & $\begin{array}{l}-0.1084 \\
(0.087)\end{array}$ & & $\begin{array}{c}-0.1046 \\
(0.107)\end{array}$ & \\
\hline Post-Soviet & $\begin{array}{c}-0.1831^{* * *} \\
(0.000)\end{array}$ & & $\begin{array}{c}-0.1872^{* * *} \\
(0.000)\end{array}$ & \\
\hline $\begin{array}{l}\text { Hausman }\left(\chi^{2}\right) \\
N\end{array}$ & 2,738 & $\begin{array}{c}32.01^{* * *} \\
2,738\end{array}$ & 2,590 & $\begin{array}{c}25.25^{* * *} \\
2,590\end{array}$ \\
\hline
\end{tabular}

$p$-values in parentheses ${ }^{*} p<0.1 ; ; * 0.05 ;{ }^{* * *} p<0.01$ 
Table 4. Foreign Assistance and Consumption Inequality: Impact of Gross Loans

\begin{tabular}{|c|c|c|c|c|}
\hline GINI & RE & RE & RE & $\mathrm{FE}$ \\
\hline & (1) & (2) & (3) & (4) \\
\hline Gross loans & $\begin{array}{c}-0.0088 \\
(0.956)\end{array}$ & $\begin{array}{c}-0.1319 \\
(0.717)\end{array}$ & $\begin{array}{c}-0.2902 \\
(0.435)\end{array}$ & $\begin{array}{c}-0.2578 \\
(0.489)\end{array}$ \\
\hline Gross loans ${ }^{2}$ & & $\begin{array}{l}9.2702 \\
(0.508)\end{array}$ & $\begin{array}{c}18.3400 \\
(0.189)\end{array}$ & $\begin{array}{c}17.4904 \\
(0.212)\end{array}$ \\
\hline Grants & $\begin{array}{c}-0.1308^{* * *} \\
(0.003)\end{array}$ & $\begin{array}{c}-0.3976^{* * *} \\
(0.000)\end{array}$ & $\begin{array}{c}-0.3150^{* * *} \\
(0.003)\end{array}$ & $\begin{array}{c}-0.3201^{* * *} \\
(0.003)\end{array}$ \\
\hline Grants $^{2}$ & & $\begin{array}{c}2.0701^{* * *} \\
(0.005)\end{array}$ & $\begin{array}{c}1.5147^{* *} \\
(0.041)\end{array}$ & $\begin{array}{c}1.5338^{* *} \\
(0.039)\end{array}$ \\
\hline Openness & & & $\begin{array}{c}0.0068^{* * *} \\
(0.002)\end{array}$ & $\begin{array}{c}0.0069^{* * *} \\
(0.002)\end{array}$ \\
\hline Govt. exp. & & & $\begin{array}{c}0.0661^{* * *} \\
(0.000)\end{array}$ & $\begin{array}{c}0.0661^{* * *} \\
(0.000)\end{array}$ \\
\hline Human cap. & & & $\begin{array}{c}0.0203^{* * *} \\
(0.000)\end{array}$ & $\begin{array}{c}0.0200^{* * *} \\
(0.000)\end{array}$ \\
\hline Polity & & & $\begin{array}{c}-0.0004^{* * *} \\
(0.006)\end{array}$ & $\begin{array}{r}-0.0004^{* * *} \\
(0.005)\end{array}$ \\
\hline Rural pop. & & & $\begin{array}{c}0.0371^{* *} \\
(0.013)\end{array}$ & $\begin{array}{c}0.0370^{* *} \\
(0.016)\end{array}$ \\
\hline Coup d'état & & & $\begin{array}{c}-0.0014 \\
(0.725)\end{array}$ & $\begin{array}{c}-0.0015 \\
(0.703)\end{array}$ \\
\hline Americas & & & $\begin{array}{l}0.0020 \\
(0.913)\end{array}$ & \\
\hline Asia & & & $\begin{array}{c}-0.1089^{* * *} \\
(0.000)\end{array}$ & \\
\hline Europe & & & $\begin{array}{c}-0.1803^{* * *} \\
(0.000)\end{array}$ & \\
\hline Middle East & & & $\begin{array}{c}-0.0488 \\
(0.286)\end{array}$ & \\
\hline Oceania & & & $\begin{array}{l}-0.1110^{*} \\
(0.081)\end{array}$ & \\
\hline Post-Soviet & & & $\begin{array}{c}-0.1743^{* * *} \\
(0.000)\end{array}$ & \\
\hline$N$ & 2,887 & 2,887 & 2,887 & 2,887 \\
\hline
\end{tabular}

$p$-values in parentheses ${ }^{*} p<0.1 ;{ }^{* *} p<0.05 ;{ }^{* * *} p<0.01$ 
Table 5. Foreign Assistance and Consumption Inequality: Total Effect of Aid

\begin{tabular}{|c|c|c|c|c|}
\hline GINI & RE & RE & RE & $\mathrm{FE}$ \\
\hline & (1) & $(2)$ & (3) & (4) \\
\hline Total aid & $\begin{array}{c}-0.1130^{* * *} \\
(0.002)\end{array}$ & $\begin{array}{c}-0.0900^{* *} \\
(0.014)\end{array}$ & $\begin{array}{c}-0.0932^{* *} \\
(0.011)\end{array}$ & $\begin{array}{c}-0.0930^{* *} \\
(0.011)\end{array}$ \\
\hline Openness & & $\begin{array}{c}0.0071^{* * *} \\
(0.001)\end{array}$ & $\begin{array}{c}0.0068^{* * *} \\
(0.002)\end{array}$ & $\begin{array}{c}0.0068^{* * *} \\
(0.002)\end{array}$ \\
\hline Govt. exp. & & $\begin{array}{c}0.0633^{* * *} \\
(0.000)\end{array}$ & $\begin{array}{c}0.0653^{* * *} \\
(0.000)\end{array}$ & $\begin{array}{c}0.0654^{* * *} \\
(0.000)\end{array}$ \\
\hline Human cap. & & $\begin{array}{c}0.0143^{* * *} \\
(0.001)\end{array}$ & $\begin{array}{l}0.0187^{* * *} \\
(0.000)\end{array}$ & $\begin{array}{c}0.0190^{* * *} \\
(0.000)\end{array}$ \\
\hline Polity & & $\begin{array}{c}-0.0004^{* * *} \\
(0.003)\end{array}$ & $\begin{array}{c}-0.0004^{* * *} \\
(0.003)\end{array}$ & $\begin{array}{c}-0.0004^{* * *} \\
(0.002)\end{array}$ \\
\hline Rural pop. & & $\begin{array}{l}0.0180 \\
(0.208)\end{array}$ & $\begin{array}{l}0.0280^{*} \\
(0.050)\end{array}$ & $\begin{array}{c}0.0301^{* *} \\
(0.043)\end{array}$ \\
\hline Coup d'état & & $\begin{array}{l}-0.0011 \\
(0.773)\end{array}$ & $\begin{array}{l}-0.0010 \\
(0.798)\end{array}$ & $\begin{array}{l}-0.0011 \\
(0.772)\end{array}$ \\
\hline Americas & & & $\begin{array}{l}0.0029 \\
(0.874)\end{array}$ & \\
\hline Asia & & & $\begin{array}{c}-0.1002^{* * *} \\
(0.000)\end{array}$ & \\
\hline Europe & & & $\begin{array}{c}-0.1772^{* * *} \\
(0.000)\end{array}$ & \\
\hline Middle East & & & $\begin{array}{l}-0.0497 \\
(0.276)\end{array}$ & \\
\hline Oceania & & & $\begin{array}{l}-0.1103^{*} \\
(0.082)\end{array}$ & \\
\hline Post-Soviet & & & $\begin{array}{c}-0.1708^{* * *} \\
(0.000)\end{array}$ & \\
\hline $\begin{array}{l}\text { Hausman }\left(\chi^{2}\right) \\
N\end{array}$ & 2,914 & 2,914 & 2,914 & $\begin{array}{c}21.65^{* * *} \\
2,914\end{array}$ \\
\hline
\end{tabular}

$p$-values in parentheses ${ }^{*} p<0.1 ;{ }^{* *} p<0.05 ;{ }^{* * * *} p<0.01$ 
Table 6. Foreign Assistance and Consumption Inequality: Estimation of On-Simultaneous Effects of Grants and Loans

\begin{tabular}{|c|c|c|c|c|}
\hline GINI & RE & $\mathrm{RE}$ & FE & FE \\
\hline & (1) & $(2)$ & (3) & (4) \\
\hline Loans & & $\begin{array}{c}0.2971^{* * *} \\
(0.004)\end{array}$ & & $\begin{array}{c}0.3001^{* * *} \\
(0.004)\end{array}$ \\
\hline Loans $^{2}$ & & $\begin{array}{c}-6.9030^{* * *} \\
(0.000)\end{array}$ & & $\begin{array}{c}-6.9723^{* * *} \\
(0.000)\end{array}$ \\
\hline Grants & $\begin{array}{c}-0.3091^{* * *} \\
(0.002)\end{array}$ & & $\begin{array}{c}-0.3105^{* * *} \\
(0.002)\end{array}$ & \\
\hline Grants $^{2}$ & $\begin{array}{l}1.5611^{* *} \\
(0.027)\end{array}$ & & $\begin{array}{c}1.5662^{* *} \\
(0.028)\end{array}$ & \\
\hline Openness & $\begin{array}{c}0.0066^{* * *} \\
(0.002)\end{array}$ & $\begin{array}{c}0.0070^{* * *} \\
(0.001)\end{array}$ & $\begin{array}{c}0.0066^{* * *} \\
(0.002)\end{array}$ & $\begin{array}{c}0.0070^{* * *} \\
(0.001)\end{array}$ \\
\hline Govt. exp. & $\begin{array}{c}0.0649^{* * *} \\
(0.000)\end{array}$ & $\begin{array}{c}0.0634^{* * *} \\
(0.000)\end{array}$ & $\begin{array}{c}0.0651^{* * *} \\
(0.000)\end{array}$ & $\begin{array}{c}0.0636^{* * *} \\
(0.000)\end{array}$ \\
\hline Human cap. & $\begin{array}{c}0.0188^{* * *} \\
(0.000)\end{array}$ & $\begin{array}{c}0.0209^{* * *} \\
(0.000)\end{array}$ & $\begin{array}{c}0.0192^{* * *} \\
(0.000)\end{array}$ & $\begin{array}{c}0.0213^{* * *} \\
(0.000)\end{array}$ \\
\hline Polity & $\begin{array}{c}-0.0004^{* * *} \\
(0.005)\end{array}$ & $\begin{array}{c}-0.0005^{* * *} \\
(0.001)\end{array}$ & $\begin{array}{c}-0.0004^{* * *} \\
(0.005)\end{array}$ & $\begin{array}{c}-0.0005^{* * *} \\
(0.001)\end{array}$ \\
\hline Rural pop. & $\begin{array}{l}0.0313^{* *} \\
(0.028)\end{array}$ & $\begin{array}{c}0.0307^{* *} \\
(0.031)\end{array}$ & $\begin{array}{c}0.0335^{* *} \\
(0.025)\end{array}$ & $\begin{array}{c}0.0335^{* *} \\
(0.025)\end{array}$ \\
\hline Coup d'état & $\begin{array}{r}-0.0012 \\
(0.762)\end{array}$ & $\begin{array}{c}-0.0004 \\
(0.916)\end{array}$ & $\begin{array}{l}-0.0013 \\
(0.736)\end{array}$ & $\begin{array}{c}-0.0005^{*} \\
(0.888)\end{array}$ \\
\hline Americas & $\begin{array}{l}0.0013 \\
(0.943)\end{array}$ & $(0.753)$ & & \\
\hline Asia & $\begin{array}{c}-0.1024^{* * *} \\
(0.000)\end{array}$ & $\begin{array}{c}-0.0981^{* * *} \\
(0.000)\end{array}$ & & \\
\hline Europe & $\begin{array}{c}-0.1781^{* * *} \\
(0.000)\end{array}$ & $\begin{array}{c}-0.1767^{* * *} \\
(0.000)\end{array}$ & & \\
\hline Middle East & $\begin{array}{c}-0.0502 \\
(0.274)\end{array}$ & $\begin{array}{c}-0.0493 \\
(0.280)\end{array}$ & & \\
\hline Oceania & $\begin{array}{l}-0.1103^{*} \\
(0.084)\end{array}$ & $\begin{array}{c}-0.1089^{*} \\
(0.086)\end{array}$ & & \\
\hline Post-Soviet & $\begin{array}{c}-0.1726^{* * *} \\
(0.000)\end{array}$ & $\begin{array}{c}-0.1712^{* * *} \\
(0.000)\end{array}$ & & \\
\hline $\begin{array}{l}\text { Hausman }\left(\chi^{2}\right) \\
N\end{array}$ & 2,914 & 2,914 & $\begin{array}{c}25.70^{* * *} \\
2,914\end{array}$ & $\begin{array}{c}27.00^{* * *} \\
2,914\end{array}$ \\
\hline
\end{tabular}

$p$-values in parentheses ${ }^{*} p<0.1 ; " * p<0.05 ;{ }^{* * *} p<0.01$ 
Table 7. Foreign Assistance and Consumption Inequality: Income Measure of Inequality

\begin{tabular}{|c|c|c|c|c|}
\hline GINI & RE & RE & RE & FE \\
\hline & (1) & (2) & (3) & (4) \\
\hline \multirow[t]{2}{*}{ Loans } & 0.2160 & $0.2852^{*}$ & $0.3004^{* *}$ & $0.3035^{* *}$ \\
\hline & (0.128) & $(0.050)$ & (0.038) & (0.035) \\
\hline \multirow[t]{2}{*}{ Loans $^{2}$} & -4.1431 & $-4.8522^{*}$ & $-4.8566^{*}$ & $-4.8686^{*}$ \\
\hline & $(0.124)$ & $(0.072)$ & (0.070) & (0.069) \\
\hline \multirow[t]{2}{*}{ Grants } & $-0.2983^{* *}$ & $-0.2374^{*}$ & $-0.3017^{* *}$ & $-0.3404^{* *}$ \\
\hline & (0.028) & $(0.084)$ & $(0.027)$ & $(0.013)$ \\
\hline \multirow[t]{2}{*}{ Grants $^{2}$} & 1.4172 & 1.0425 & 1.4483 & $1.6651^{*}$ \\
\hline & (0.146) & $(0.288)$ & $(0.137)$ & $(0.090)$ \\
\hline \multirow[t]{2}{*}{ Openness } & & $0.0155^{* * *}$ & $0.0137^{* * *}$ & $0.0136^{* * *}$ \\
\hline & & $(0.000)$ & $(0.000)$ & $(0.000)$ \\
\hline \multirow[t]{2}{*}{ Govt. exp. } & & -0.0002 & & 0.0034 \\
\hline & & $(0.986)$ & $(0.800)$ & $(0.796)$ \\
\hline \multirow[t]{2}{*}{ Human cap. } & & 0.0062 & $0.0121^{* *}$ & $0.0145^{* *}$ \\
\hline & & (0.303) & $(0.045)$ & (0.023) \\
\hline \multirow[t]{2}{*}{ Polity } & & -0.0002 & -0.0002 & -0.0002 \\
\hline & & (0.296) & (0.332) & (0.388) \\
\hline \multirow[t]{2}{*}{ Rural pop. } & & $0.0335^{*}$ & $0.0383^{* *}$ & $0.0465^{* *}$ \\
\hline & & $(0.082)$ & $(0.043)$ & (0.024) \\
\hline \multirow[t]{2}{*}{ Coup d'état } & & 0.0034 & 0.0042 & 0.0040 \\
\hline & & $(0.480)$ & $(0.425)$ & $(0.447)$ \\
\hline \multirow[t]{2}{*}{ Americas } & & & $-0.0899^{* * *}$ & \\
\hline & & & (0.000) & \\
\hline \multirow[t]{2}{*}{ Asia } & & & $-0.1614^{* * *}$ & \\
\hline & & & $(0.000)$ & \\
\hline \multirow[t]{2}{*}{ Europe } & & & $-0.2560^{* * *}$ & \\
\hline & & & $(0.000)$ & \\
\hline \multirow[t]{2}{*}{ Middle East } & & & $-0.1630^{* * *}$ & \\
\hline & & & $(0.000)$ & \\
\hline \multirow[t]{2}{*}{ Oceania } & & & $-0.1441^{* *}$ & \\
\hline & & & $(0.020)$ & \\
\hline \multirow[t]{2}{*}{ Post-Soviet } & & & $-0.1650^{* * *}$ & \\
\hline & & & $(0.000)$ & \\
\hline Hausman $\left(\chi^{2}\right)$ & & & & $24.15^{* * *}$ \\
\hline$N$ & 2,949 & 2,949 & 2,949 & 2,949 \\
\hline
\end{tabular}

$p$-values in parentheses ${ }^{*} p<0.1 ; * * 0.05 ;{ }^{* * *} p<0.01$ 
Table 8. Foreign Assistance and Consumption inequality: Multiple Fixed Effects Absorbtion Model

\begin{tabular}{|c|c|c|c|}
\hline GINI & FE & $\mathrm{FE}$ & $\mathrm{FE}$ \\
\hline & (1) & $(2)$ & (4) \\
\hline \multirow[t]{2}{*}{ Loans } & 0.0501 & $0.2830^{* *}$ & $0.3332^{* * *}$ \\
\hline & (0.643) & (0.014) & (0.003) \\
\hline \multirow[t]{2}{*}{ Loans $^{2}$} & & $-5.6100^{* *}$ & $-6.2810^{* * *}$ \\
\hline & & (0.014) & (0.002) \\
\hline \multirow[t]{2}{*}{ Grants } & $-0.1431^{* * *}$ & $-0.4206^{* * *}$ & $-0.3203^{* * *}$ \\
\hline & (0.005) & (0.001) & (0.008) \\
\hline \multirow[t]{2}{*}{ Grants $^{2}$} & & $2.3370^{* * *}$ & $1.7462^{* * *}$ \\
\hline & & (0.001) & (0.009) \\
\hline \multirow[t]{2}{*}{ Openness } & & & $0.0067^{* * *}$ \\
\hline & & & (0.007) \\
\hline \multirow[t]{2}{*}{ Govt. exp. } & & & $0.0634^{* * *}$ \\
\hline & & & (0.000) \\
\hline \multirow[t]{2}{*}{ Human cap. } & & & $0.0209^{* *}$ \\
\hline & & & $(0.000)$ \\
\hline \multirow[t]{2}{*}{ Polity } & & & $-0.0004^{* *}$ \\
\hline & & & (0.010) \\
\hline \multirow[t]{2}{*}{ Rural pop. } & & & $0.0359^{* * *}$ \\
\hline & & & (0.008) \\
\hline \multirow[t]{2}{*}{ Coup d'état } & & & -0.0010 \\
\hline & & & $(0.822)$ \\
\hline$N$ & 2,914 & 2,914 & 2,914 \\
\hline
\end{tabular}

$p$-values in parentheses ${ }^{*} p<0.1 ; * * 0.05 ;{ }^{* * *} p<0.01$ 
Table 9. Foreign Assistance and Consumption Inequality: Results for GDP per Capita Quartile Subsets

\begin{tabular}{|c|c|c|c|c|c|}
\hline \multirow{3}{*}{ GINI } & 1st Quarter & 2nd Quarter & 3d Quarter & 4th Quarter & FE $100^{\text {th }}$ percentile \\
\hline & FE & FE & FE & FE & FE \\
\hline & (1) & $(2)$ & (3) & (4) & (5) \\
\hline Loans & $\begin{array}{c}0.4737^{* *} \\
(0.021)\end{array}$ & $\begin{array}{l}0.0978 \\
(0.589)\end{array}$ & $\begin{array}{l}-0.0471 \\
(0.786)\end{array}$ & $\begin{array}{c}-1.2852^{* *} \\
(0.022)\end{array}$ & $\begin{array}{c}-1.1109 * * \\
(0.017)\end{array}$ \\
\hline Loans $^{2}$ & $\begin{array}{c}-4.6312^{*} \\
(0.079)\end{array}$ & $\begin{array}{c}-2.4533 \\
(0.497)\end{array}$ & $\begin{array}{l}4.5905 \\
(0.446)\end{array}$ & $\begin{array}{l}29.1704 \\
(0.504)\end{array}$ & \\
\hline Grants & $\begin{array}{c}-0.7331^{* * *} \\
(0.001)\end{array}$ & $\begin{array}{c}0.9975^{* * *} \\
(0.000)\end{array}$ & $\begin{array}{c}-0.4012^{* *} \\
(0.015)\end{array}$ & $\begin{array}{c}-0.2576 \\
(0.441)\end{array}$ & $\begin{array}{l}-0.2301 \\
(0.494)\end{array}$ \\
\hline Grants $^{2}$ & $\begin{array}{c}3.7567^{* * *} \\
(0.001)\end{array}$ & $\begin{array}{c}-4.5663^{* * *} \\
(0.004)\end{array}$ & $\begin{array}{c}3.0082^{* * *} \\
(0.001)\end{array}$ & $\begin{array}{c}2.1716 \\
(0.709)\end{array}$ & $\begin{array}{l}1.6458 \\
(0.779)\end{array}$ \\
\hline Openness & $\begin{array}{c}0.0191^{* *} \\
(0.031)\end{array}$ & $\begin{array}{c}0.0103^{* *} \\
(0.012)\end{array}$ & $\begin{array}{c}0.0100^{* *} \\
(0.010)\end{array}$ & $\begin{array}{c}0.0075^{* *} \\
(0.028)\end{array}$ & $\begin{array}{c}0.0072^{* *} \\
(0.031)\end{array}$ \\
\hline Govt. exp. & $\begin{array}{r}-0.0212 \\
(0.479)\end{array}$ & $\begin{array}{c}0.0707^{* * *} \\
(0.000)\end{array}$ & $\begin{array}{c}0.0749^{* * *} \\
(0.000)\end{array}$ & $\begin{array}{c}-0.0476^{* *} \\
(0.016)\end{array}$ & $\begin{array}{c}-0.0469^{* *} \\
(0.017)\end{array}$ \\
\hline Human cap. & $\begin{array}{c}-0.0502^{* *} \\
(0.024)\end{array}$ & $\begin{array}{c}0.0159^{* *} \\
(0.049)\end{array}$ & $\begin{array}{c}0.0613^{* * *} \\
(0.000)\end{array}$ & $\begin{array}{l}0.0215^{*} \\
(0.053)\end{array}$ & $\begin{array}{c}0.0219^{* *} \\
(0.045)\end{array}$ \\
\hline Polity & $\begin{array}{c}-0.0012^{* * *} \\
(0.006)\end{array}$ & $\begin{array}{c}-0.0008^{* * *} \\
(0.003)\end{array}$ & $\begin{array}{l}0.0001 \\
(0.530)\end{array}$ & $\begin{array}{l}0.0001 \\
(0.752)\end{array}$ & $\begin{array}{l}0.0001 \\
(0.765)\end{array}$ \\
\hline Rural pop. & $\begin{array}{c}-0.2302^{* * *} \\
(0.000)\end{array}$ & $\begin{array}{c}0.0677^{* *} \\
(0.011)\end{array}$ & $\begin{array}{c}0.2220^{* * *} \\
(0.000)\end{array}$ & $\begin{array}{c}0.0788^{* * *} \\
(0.001)\end{array}$ & $\begin{array}{c}0.0778^{* * *} \\
(0.001)\end{array}$ \\
\hline Coup d'état & $\begin{array}{c}-0.0025 \\
(0.805)\end{array}$ & $\begin{array}{c}-0.0016 \\
(0.708)\end{array}$ & $\begin{array}{l}0.0056 \\
(0.434)\end{array}$ & $\begin{array}{r}-0.0019 \\
(0.682)\end{array}$ & $\begin{array}{c}-0.0020 \\
(0.661)\end{array}$ \\
\hline$N$ & 736 & 726 & 735 & 704 & 704 \\
\hline
\end{tabular}

$p$-values in parentheses ${ }^{*} p<0.1 ; ; * 0.05 ;{ }^{* * *} p<0.01$ 


\section{APPENDIX A}

A1. List of Countries Used in the Models

\begin{tabular}{|c|c|c|}
\hline Albania & Indonesia & Sierra Leone \\
\hline Algeria & Jamaica & Slovenia \\
\hline Angola & Jordan & South Africa \\
\hline Argentina & Kazakhstan & Sri Lanka \\
\hline Armenia & Kenya & Tajikistan \\
\hline Bangladesh & Lesotho & Thailand \\
\hline Benin & Liberia & Togo \\
\hline Botswana & Madagascar & Trinidad and Tobago \\
\hline Brazil & Malawi & Tunisia \\
\hline Burkina Faso & Malaysia & Turkey \\
\hline Burundi & Mali & Uganda \\
\hline Cambodia & Mauritania & Ukraine \\
\hline Cameroon & Mauritius & Uruguay \\
\hline Central African Republic & Mexico & Zambia \\
\hline Chile & Mongolia & \\
\hline Colombia & Morocco & \\
\hline Costa Rica & Mozambique & \\
\hline Croatia & Namibia & \\
\hline Cyprus & Nepal & \\
\hline Dominican Republic & Nicaragua & \\
\hline Ecuador & Niger & \\
\hline El Salvador & Nigeria & \\
\hline Ethiopia & Pakistan & \\
\hline Fiji & Panama & \\
\hline Gabon & Paraguay & \\
\hline Ghana & Peru & \\
\hline Guatemala & Philippines & \\
\hline Haiti & Rwanda & \\
\hline Honduras & Senegal & \\
\hline India & Serbia & \\
\hline
\end{tabular}


A2. Aid Specialization Classification

\begin{tabular}{|c|c|c|}
\hline Loan oriented & \multicolumn{2}{|c|}{ Grant oriented } \\
\hline Brazil & Albania & Madagascar \\
\hline Chile & Algeria & Mali \\
\hline India & Angola & Mauritania \\
\hline Indonesia & Argentina & Mauritius \\
\hline Pakistan & Bangladesh & Mongolia \\
\hline \multirow[t]{23}{*}{ Turkey } & Benin & Mozambique \\
\hline & Botswana & Namibia \\
\hline & Burkina Faso & Nepal \\
\hline & Burundi & Nicaragua \\
\hline & Cambodia & Niger \\
\hline & Cameroon & Nigeria \\
\hline & Central African Republic & Panama \\
\hline & Costa Rica & Paraguay \\
\hline & Croatia & Peru \\
\hline & Cyprus & Philippines \\
\hline & Ecuador & Rwanda \\
\hline & El Salvador & Senegal \\
\hline & Ethiopia & Serbia \\
\hline & Fiji & Sierra Leone \\
\hline & Gabon & South Africa \\
\hline & Guatemala & Tajikistan \\
\hline & Haiti & Thailand \\
\hline & Honduras & Togo \\
\hline & Jordan & Trinidad and Tobago \\
\hline & Kazakhstan & Uganda \\
\hline & Kenya & Ukraine \\
\hline & Lesotho & Uruguay \\
\hline & Liberia & Zambia \\
\hline
\end{tabular}

